\title{
RANCANGAN KAWASAN AGROWISATA DI DESA BUKIT RAYA KECAMATAN TENGGARONG SEBERANG KABUPATEN KUTAI KARTANEGARA, KALIMANTAN TIMUR
}

\author{
Anton Nurcahyo $\circledast^{1)}$, Eman Sukmana $\left(^{2)}\right.$, Bhanu Rizfa Hakim $\left(^{3)}\right.$, Rizky Sulvika Pusparinda $\left(^{4)}\right.$, dan Adi Chandra $\left(^{5)}\right.$ \\ ${ }^{1,2}$ Usaha Perjalanan Wisata, Politeknik Negeri Samarinda \\ ${ }^{3}$ Arsitektur, Politeknik Negeri Samarinda \\ ${ }^{4}$ Teknik Mesin, Politeknik Negeri Samarinda \\ ${ }^{5}$ Kepegawaian, Politeknik Negeri Samarinda \\ 1,2,3,4,5J1. Dr. Ciptomangunkusumo, Kampus Gunung Lipan, Samarinda, 75131 \\ E-mail : antonnurcahyo@polnes.ac.id ${ }^{1)}$, emansukmana@polnes.ac.id ${ }^{2)}$, bhanuarsitek@ gmail.com ${ }^{3)}$, \\ rinda.rizky@polnes.ac.id ${ }^{4)}$, adichandrapolnes@gmail.com ${ }^{5)}$
}

\begin{abstract}
ABSTRAK
Pemerintah Kabupaten Kutai Kartanegara (Kukar) telah menetapkan bahwa sektor komersial umum khususnya pariwisata merupakan sektor penting dalam meningkatkan pendapatan daerah, dengan indikator jumlah kunjungan dan pergerakan wisatawan, serta rata-rata tingkat hunian akomodasi yang berada di Kukar selama kegiatan wisata. Sesuai dengan program nasional yang menjelaskan bahwa sektor pariwisata berperan penting dalam regulasi keuangan selama kurang lebih 5 tahun (sebelum penyebaran Covid-19) mengingat peningkatan jumlah wisatawan mancanegara setiap tahun. Bukit Raya merupakan salah satu desa di Kecamatan Tenggarong Seberang Kabupaten Kutai Kartanegara yang memiliki potensi komersial di bidang pertanian. Kemudian, setelah dilakukan penelitian awal oleh penulis, hasilnya luar biasa dengan potensi lahan pertanian yang luas dengan tingkat kebersihan yang tinggi dan organisir dengan baik, Bukit Raya memiliki peluang untuk dikembangkan menjadi kawasan agrowisata terbesar di Provinsi Kalimantan Timur dengan produk unggulan Mina-Padi (kombinasi ikan dan padi). Penelitian ini bertujuan untuk menata dan mendesain kawasan agrowisata dengan teknik pemetaan dan pembuatan desain kawasan (site plan) sebagai metode penelitian deskriptif kualitatif. Hasil analisis yaitu memberikan gambaran perencanaan kawasan agrowisata pedesaan Bukit Raya secara keseluruhan berupa penanda peta sebagai implementasi zonasi daya tarik wisata serta rancangan kawasan agrowisata (site plan) yang berbasis pada pertanian. Perancangan kawasan pertanian dilakukan dengan menggunakan pendekatan perencanaan, zonasi dan desain arsitektur menggunakan penanda peta (marker map) dan perangkat lunak lansekap. Hasil perencanaan Desa Bukit Raya kemudian dibandingkan dengan konsep kategori agrowisata dan dianalisis sesuai dengan potensi kendala yang mungkin dihadapi masyarakat.
\end{abstract}

Kata Kunci: Desain Kawasan, Agrowisata, Desa Wisata, Bukit Raya, Zonasi

\section{PENDAHULUAN}

Di Indonesia, sektor pariwisata telah memainkan peran penting dalam perekonomian negara selama kurang lebih lima tahun terakhir (Damanik dkk., 2015) (sebelum penyebaran Covid-19) dilihat dari pertumbuhan jumlah wisatawan asing setiap tahun. Dengan demikian, UNWTO (United Nation of World Tourism Organization) dan UU No. 25 Tahun 2000 tentang Program Perencanaan Nasional menekankan kepariwisataan sebagai sektor unggulan yang menjadi kunci pembangunan daerah dan peningkatan kesejahteraan masyarakat, yang memiliki fungsi dan peran (UNWTO - United Nations World Tourism Organization, 2015), yaitu: Pro-job; Pro-growth; Propoor; dan Pro-environment.

Keempat hal tersebut menginisiasikan munculnya pendekatan pariwisata berbasis masyarakat sebagai alternatif pembangunan berkelanjutan dengan melibatkan masyarakat sebagai subjek aktif dalam setiap kegiatan pengembangan pariwisata di wilayah tersebut
(Marinovski, 2018). Konsep Desa Agrowisata merupakan representasi dari pengembangan pariwisata berbasis masyarakat yang diharapkan dapat mempercepat pertumbuhan ekonomi, sosial, budaya dan lingkungan di desa tersebut. Desa wisata dapat diartikan sebagai bentuk integratif dari beberapa unsur pariwisata meliputi atraksi, aksesibilitas, dan amanitas yang dihadirkan dalam satu wilayah geografis melalui suatu struktur masyarakat yang terintegrasi secara utuh dengan keunikan kehidupan, adat dan tradisi (Goodwin and Santilli, 2017).

Sejalan dengan pemikiran di atas, Pemerintah Kabupaten Kutai Kartanegara menerjemahkan pariwisata sebagai salah satu sektor andalan Kukar dalam meningkatkan Pendapatan Asli Daerah (PAD), dengan indikator jumlah kunjungan dan pergerakan wisatawan di destinasi wisata Kukar dan rata-rata menginap di Akomodasi Kukar selama kegiatan wisata (Badan Pusat Statistik Kabupaten Kutai Kartanegara, 2020).

Penelitian ini berfokus pada analisis potensi wisata berbasis pertanian padi (mina padi) yang dilakukan 
dengan pendekatan wisata berbasis masyarakat melalui survei lapangan secara langsung. Metode ini dilakukan dengan cara hidup bersama sebagai sebuah komunitas di Desa Bukit Raya, sehingga peneliti terlibat langsung dengan berbagai aktivitas masyarakat sehari-hari.

Pembangunan dan pengembangan desa wisata yang ideal harus memperhatikan konsep keberlanjutan yang mengacu pada basic thinking yang berbasis atraksi pertanian dan kearifan masyarakat setempat.

Sehingga, pada penelitian ini penulis merujuk pada dasar-dasar teori yang relevan dengan sub topik yang dibahas. Hal ini tentunya secara common sense menarik beberapa orang dalam kelompok petani yang ada di Desa Bukit Raya untuk mengembangkan desanya menjadi desa wisata melalui pertanian. Berdasarkan hasil identifikasi, Desa Bukit Raya memiliki potensi wisata yang dapat dikembangkan menjadi objek wisata, rinciannya yang akan disajikan pada Bab Hasil Penelitian. Namun permasalahannya, masyarakat dan Pemerintah Desa Bukit Raya belum memiliki gambaran yang jelas tentang desain pengembangan sektor pariwisata tersebut. Sehingga membutuhkan bantuan pihak ketiga untuk membantu merancang bersama Perancangan Kawasan Agrowisata Bukit Raya dan turunannya.

\section{RUANG LINGKUP}

Lingkup penelitian ini dibatasi hanya pada wilayah Desa Bukit Raya Kecamatan Tenggarong Seberang, serta hanya membahas tentang perancangan desain kawasan agrowisata. Dalam penelitian ini permasalahan mencakup:

1. Cakupan permasalahan berkaitan dengan perancangan desain kawasan agrowisata di Desa Bukit Raya sebagai pedoman bagi desa untuk menentukan prioritas pembangunan desa.

2. Batasan-batasan dalam penelitian ini terletak pada perancangan desain kawasan menggunakan alat bantu penelitian UTM Geo Map untuk Marking Map dan desain 2D kawasan agrowisata.

3. Rencana hasil yang didapatkan berupa pemetaan zonasi daya tarik wisata dan desain kawasan (site plan) Desa Bukit Raya yang berbasis pada pertanian, peternakan, dan kearifan lokal masyarakat.

\section{BAHAN DAN METODE}

Bahan dan metode dalam penelitian ini digunakan untuk mendeskripsikan bahan dan alat-alat analisis yang relevan dengan topik penelitian ini. Sehingga, dapat memperoleh hasil yang maksimal sebagai hasil kajian terhadap proses perancangan desain kawasan agrowisata di Desa Bukit Raya.

\subsection{Agrowisata}

Agrowisata adalah model bisnis yang semakin populer karena petani Indonesia menyadari kebutuhan untuk mendiversifikasi operasi mereka dan menambah pendapatan pertanian mereka. Selain itu, ada keinginan publik yang berkembang untuk terlibat dalam pengalaman pedesaan dan kegiatan rekreasi di luar ruangan. Dengan menggabungkan pertanian dan pariwisata, agrowisata menawarkan pengalaman pedesaan kepada penduduk perkotaan dan diversifikasi ekonomi kepada petani. Perencanaan untuk agrowisata membutuhkan pemikiran ke depan, proses berbasis lokal. Perencana harus mengakui pertanian sebagai penggunaan lahan dan bisnis. Secara umum dipahami sebagai model bisnis yang menghubungkan produksi/pengolahan pertanian dengan pariwisata untuk menarik pengunjung ke pertanian, hutan, atau bisnis pertanian lainnya untuk tujuan menghibur dan/atau mendidik pengunjung dan menghasilkan pendapatan untuk pertanian, hutan, atau pemilik usaha (Putra, Arkan and Atmaja, 2020).

\subsection{Pariwisata}

Hermantoro (2017) menjelaskan bahwa pariwisata merupakan domain pembangunan dan bukan sektor pembangunan, karena domain berisi ruang berbagai kegiatan penunjang sektoral. Pariwisata dibangun atas sinergi antar sektor dan outputnya sehingga menghasilkan output kolektif (Hermantoro, 2017). Dengan demikian, pariwisata diibaratkan seperti sebuah orkestra yang dipimpin oleh seorang konduktor dengan beberapa musisi dengan menggunakan skor sebagai tanda arah. Hermantoro (2017) menggambarkan bahwa untuk menghasilkan musik "Wonderful Indonesia", konduktor (Kemenpar) harus mampu mengarahkan dan menggerakkan lembaran musiknya (master plan pariwisata) yang mudah dipahami oleh musisi (sektor/pelaku pariwisata) sesuai dengan keahlian dan tugasnya masing-masing (Wulandari, 2017).

\subsection{Potensi dan Daya Tarik Wisata}

Manusia dapat digolongkan ke dalam kelompok homo turistikus, karena sifatnya yang suka bepergian untuk mencari pengetahuan baru dan hal-hal yang menarik dan menantang. Potensi pariwisata (tourism resources) biasa disebut sebagai sumber daya pariwisata yang merupakan benih-benih unggulan pariwisata yang belum dikelola dengan baik, sehingga belum dapat dikunjungi wisatawan dalam jumlah yang signifikan. Potensi tersebut akan menjadi daya tarik wisata apabila dikelola dengan baik dan dapat dikunjungi wisatawan dalam jumlah yang signifikan. Sedangkan tempat wisata secara singkat dijelaskan dalam UU No. 10 Tahun 2009, bahwa daya tarik wisata berbasis alam, budaya (berwujud dan tidak berwujud), dan buatan yang merupakan komponen destinasi yang dapat dibedakan dari komponen destinasi pariwisata lainnya seperti fasilitas umum dan fasilitas pariwisata, aksesibilitas, dan komunitas (Kementerian Hukum dan Hak Asasi Manusia, 2009). 


\subsection{Desa Wisata}

Desa wisata tersebut merupakan perwujudan dari konsep Community-Based Tourism (Wisata Berbasis Masyarakat). Dalam konsep ini, masyarakat lokal memiliki peran penting dalam kegiatan pariwisata agar masyarakat lokal dapat menikmati manfaat pariwisata, tidak hanya menjadi objek wisata atau penonton. Desa wisata merupakan bentuk paduan antara atraksi, akomodasi dan fasilitas pendukung yang dihadirkan dalam suatu struktur kehidupan masyarakat yang menyatu dengan tata cara dan tradisi yang berlaku. Hal ini merupakan salah satu solusi yang dilakukan untuk meningkatkan kesejahteraan masyarakat pedesaan melalui pengembangan desa wisata. Desa wisata sebagai produk wisata yang melibatkan anggota masyarakat desa dengan segala perangkat yang dimiliki. Desa wisata tidak hanya mempengaruhi perekonomian, tetapi juga dapat melestarikan lingkungan alam dan sosial budaya masyarakat, terutama yang berkaitan dengan nilai-nilai kebersamaan, kekeluargaan, dan gotong royong. Dengan demikian, kelestarian alam dan sosial budaya masyarakat akan menjadi daya tarik bagi wisatawan yang melakukan perjalanan (Sukmana, Brahmantyo and Mumin, 2018).

\subsection{Pariwisata Berbasis Masyarakat}

Secara umum, Community-Based Tourism disebut sebagai pengembangan pariwisata yang berbasis pada masyarakat atau dapat juga dikatakan sebagai perencanaan pembangunan desa secara partisipatif (Bihamding, 2017). Pariwisata berbasis masyarakat merupakan konsep pengembangan destinasi wisata melalui pemberdayaan masyarakat lokal. Dimana masyarakat ikut serta dalam merencanakan, mengelola, dan menyampaikan pendapat. Jenis wisata ini merupakan alternatif dari wisata mainstream yang sudah ada saat ini. CBT harus memperhatikan aspek kelestarian lingkungan, sosial, dan budaya karena dalam penerapannya berfungsi sebagai alat untuk pengembangan masyarakat dan pelestarian lingkungan atau dengan kata lain CBT adalah alat untuk pengembangan pariwisata yang berkelanjutan (Srithong, Suthitakon and Karnjanakit, 2019). Masyarakat yang terlibat dalam kegiatan pariwisata dengan pendekatan CBT memiliki kontrol yang besar dalam keterlibatannya untuk mengembangkan dan mengelola kegiatan pariwisata yang mampu memberikan manfaat ekonomi tidak hanya bagi masyarakat yang terlibat langsung, tetapi juga bermanfaat bagi masyarakat yang tidak terlibat langsung karena menimbulkan multiplier effect (Andin, 2013).

\subsection{Subjek dan Objek Penelitian}

Subjek dalam penelitian ini meliputi orang-orang yang terlibat langsung dan pihak swasta yang berkepentingan dengan pengembangan desa wisata sebagai informan, antara lain: Kepala Desa, Tokoh Adat, Tokoh Masyarakat, Tokoh Pemuda, Masyarakat Bukit Raya, Pemerintah Kabupaten Kukar, Pariwisata Kukar
Kantor, Pihak Swasta (PT. BBE), dan peneliti sebelumnya yang dapat dihubungi.

Objek yang diteliti dalam penelitian ini adalah struktur kehidupan masyarakat Desa Bukit Raya secara keseluruhan yang diidentifikasi berdasarkan konsep pembagian daya tarik wisata yaitu alam, budaya, dan buatan untuk kemudian di konversikan berdasarkan kriteria mengembangkan desa wisata dengan formula 4A+1C yaitu atraksi, amanitas, aksesibilitas, ancillary, dan keterlibatan masyarakat.

\subsection{Tahapan Penelitian}

Tahapan penelitian yang akan dilakukan mengadopsi 9 langkah strategis yang telah dirumuskan Kementerian Pariwisata, seperti pada Gambar 1.

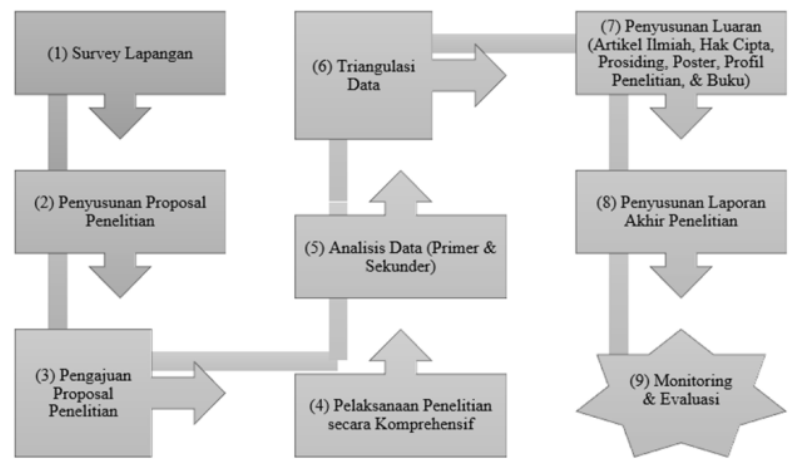

Gambar 1. Diagram Alir Tahapan Penelitian

Sumber: (Sukmana, Brahmantyo and Hira, 2020)

\subsection{Alat Bantu Penelitian}

Alat bantu penelitian yang digunakan terdiri dari 2 (dua) aplikasi yang berbasis mobile yaitu UTM Geo Map App, dan aplikasi yang berbasis pada software komputer yaitu Real time Landscaping Architecture. Kedua alat bantu ini sangat penting posisinya sebagai pemrosesan dan keluaran data yang objektif dan efisien dalam proses perancangan desain kawasan agrowisata di Desa Bukit Raya.

\subsubsection{UTM Geo Map App}

UTM Geo Map merupakan aplikasi android yang dapat membantu pekerjaan menentukan Koordinat, Peta, SIG, dan Analisis Spasial. Sehingga aplikasi ini dapat menjadi data awal untuk menentukan letak koordinat dan menandai objek wisata di Desa Bukit Raya dengan bantuan data satelit. Sehingga proses ini dapat mempermudah dalam pembuatan Peta Interaktif Destinasi Agrowisata Bukit Raya yang dilengkapi dengan informasi yang dibutuhkan pengunjung. Berikut adalah Gambar 2 tampilan halaman utama aplikasi UTM Geo Map. 


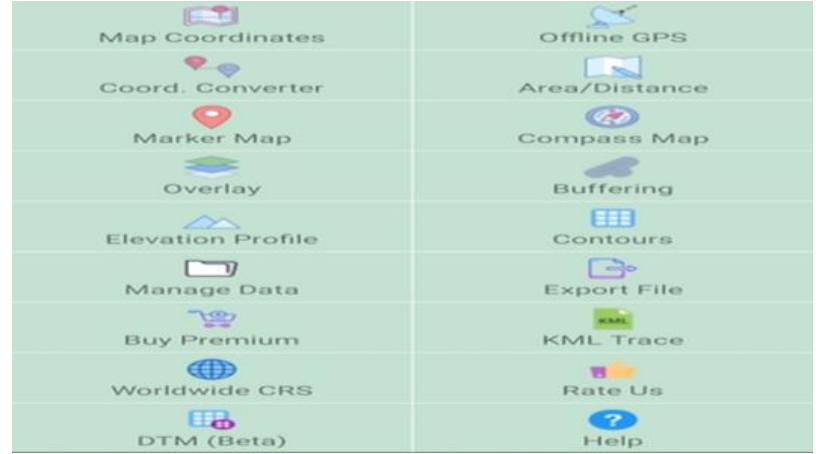

Gambar 2. Main Page UTM Geo Map

\subsubsection{Real time Landscaping Software}

Software berbasis komputer yang digunakan untuk mendesain rumah, dek, pagar, taman, dan lain-lain dengan fitur dan alat tambahan yang lengkap. Perangkat lunak ini juga dapat merancang sistem irigasi, detail penamaan, dan gambar CAD dengan ukuran dan skala yang akurat.

\section{PEMBAhasan}

Potensi Desa Bukit Raya terletak pada kekayaan sektor pertanian padi dan campur sari, mina padi (gabungan antara perikanan dan ladang padi), peternakan (ikan lele, kambing, dan sapi), industri kreatif (doran cangkul dan batu bata), serta kearifan lokal masyarakat yang menarik seperti kegiatan memancing ikan, nganco ikan dan udang di parit-parit sawah yang luas. Selain itu Desa Bukit Raya juga memiliki potensi alam berupa 2 (dua) buah Embung penampungan air bersih di lahan eks tambang batu bara. Meskipun bekas tambang batu bara, namun airnya tidak berbahaya dan bisa dikonsumsi masyarakat. Hal ini sudah dilakukan penelitian oleh tim kesehatan untuk mengukur kadar air di kedua Embung Desa Bukit Raya. Potensi-potensi tersebut secara teoretis dapat diidentifikasi sebagai daya tarik wisata yang cukup lengkap untuk perintisan Desa Wisata Bukit Raya.

\subsection{Deskripsi Lokasi Penelitian}

Desa Bukit Raya merupakan desa dengan luas terkecil $10,10 \mathrm{~km} 2$ atau hanya 2,28\% dari luas wilayah Kecamatan Tenggarong Seberang (Badan Pusat Statistik Kabupaten Kutai Kartanegara, 2020).

\subsection{Proses Perencanaan}

Masyarakat yang berkepentingan untuk mendiversifikasi barang dagangan dan ekonomi asli mereka, mengakui perlunya mendukung operasi pertanian dan mengatur agrowisata. Agrowisata ini harus menjadi bagian dari metode perencanaan komprehensif masyarakat antara pemangku kepentingan dan masyarakat di Bukit Raya, yang mungkin menawarkan landasan bagi upaya agriwisata, dengan tujuan terkait untuk masa depan (Jafaruddin, Noor and Karyani, 2020). Jika sebuah komunitas sudah memiliki rencana komprehensif yang diadopsi, mungkin di amendemen untuk memasukkan agritourism. Karena karakteristik, sikap, dan nilai yang berbeda di antara komunitas, rencana komprehensif yang berhasil untuk satu komunitas pada dasarnya tidak akan berhasil untuk yang lain. Rencana komprehensif yang jujur mencerminkan budaya lokal di bidang pertanian dan membantu mencapai identitas komunitas tunggal sebagai petani sambil memastikan bahwa keinginan dan keinginan semua penduduk dianggap sebagai program prioritas (Indrawati, 2019).

Petani, perencana, warga yang tertarik, dan petugas pemilihan harus bekerja sama untuk membuat visi bagi masyarakat dan mengembangkan rencana dan alat implementasi. selama proses desain, perlu dipastikan bahwa tepi dan beban moneter dan restriktif dialokasikan secara adil. setiap masyarakat dapat mencapai keseimbangannya sendiri sesuai dengan karakteristik, sikap, dan nilai-nilainya. Dengan visi bersama tentang perlindungan lahan pertanian dan mempromosikan agrowisata, petani, perencana, warga, dan petugas asli dapat menjadi mitra yang kuat dalam perencanaan.

Kemitraan publik-swasta bahkan dapat menawarkan dukungan untuk proses desain. Undang-undang federal, negara bagian, dan lokal serta pilihan yang berbeda dapat secara langsung berdampak pada penggunaan pertanian lokal. Misalnya, desa Bukit Raya memberikan perlindungan operasi pertanian yang datang setelah peraturan daerah. Selain itu, program bantuan yang diberikan oleh Pemerintah Daerah di bidang pertanian seperti bantuan pengadaan semenisasi pematang sawah, jalan, air, saluran pembuangan, dan berbagai jenis pembangunan dapat memiliki dampak penting pada pertanian di Desa Bukit Raya. Sehingga diharapkan menjadi bekal kolaborasi antara kebijakan daerah (Provinsi dan Kabupaten) dengan kebijakan lokal (di tingkat desa). Setiap komunitas dan kelompok pertanian di Desa Bukit Raya dapat memantau keseimbangan yang sesuai antara kebijakan daerah dan insentif yang diberikan. Keseimbangan harus didukung oleh anggaran untuk pengadaan berbagai alat yang dibutuhkan untuk memenuhi permintaan pasar (demand). Sehingga terwujud efektivitas biaya dari berbagai pendekatan yang dianalisis untuk kepentingan di masa depan agar mengetahui langkah-langkah efektif dalam perancangan kawasan agrowisata di komunitas tertentu.

\subsection{Zonasi Kawasan Agrowisata}

Dalam mempromosikan agrowisata, masyarakat Desa Bukit Raya tidak boleh kehilangan keseimbangan antara kepedulian yang sah terhadap kesehatan masyarakat, keselamatan dan kesejahteraan otoritas lokal; pelestarian karakter pedesaan kabupaten; dan memberikan peluang bagi tumbuhnya pariwisata berkelanjutan di pedesaan (Lee and Nam, 2007). Tata cara perencanaan adalah alat utama untuk menerapkan rencana menyeluruh dan alat penting dalam menjaga keseimbangan ini. Perencanaan dapat membantu mencapai tujuan masyarakat dengan mengatur penggunaan lahan, intensitas penggunaan, dan standar pembangunan (misalnya, parkir, keamanan, dan 
rambu). Aturan rumah tangga atau kontrol lokal merupakan tulang punggung perencanaan penggunaan lahan di Bukit Raya. Secara khusus ditolak atau dipesan oleh Komunitas Bukit Raya. Penggunaan berdampak tinggi harus memerlukan tinjauan publik dari kegiatan agrowisata yang diusulkan. Misalnya, Kabupaten Hancock mengeluarkan peraturan zonasi yang membedakan antara jenis agribisnis berdasarkan intensitas penggunaannya.

\subsection{Pendekatan dan Metode Desain}

Untuk menghasilkan hasil yang konkrit dan pasti dalam proses perancangan arsitektur pusat agrowisata merah muda di Bukit Raya, digunakan kombinasi metode perancangan dengan memopulerkan konsep berdasarkan ide. Desain dapat digunakan dan dilakukan di semua tahap selanjutnya. Gagasan menanam padi dan perkebunan lainnya (buah-buahan dan sayuran) sebagai daya tarik wisata dan pertukaran lintas budaya adalah hal baru di Kalimantan Timur, dengan beberapa pengecualian. Perkebunan pertanian asing di provinsi ini terutama menanam sayuran dan buah-buahan, dan budidaya bunga kurang lebih diabaikan. Untuk alasan ini, pendekatan desain berbasis konsep memberikan peluang untuk mengubah ide menjadi desain yang eksotis, sementara pendekatan berbasis pola dapat digunakan sebagai alat perencanaan biaya. Metode ini menggunakan ciri-ciri utama padi dan perkebunan lainnya, seperti: bentuk, warna, dan kontur (Paneva, 2018).

Fungsi "Marker Map" pada menu utama peta UTM dapat digunakan untuk menandai objek-objek potensial dalam pengembangan agrowisata di desa Bukit Raya. Pada tanggal 2 Februari 2021, tim melakukan survei awal untuk penelitian lapangan, dan hasilnya berupa penanda objek di desa Bukit Raya seperti pada Gambar 3.

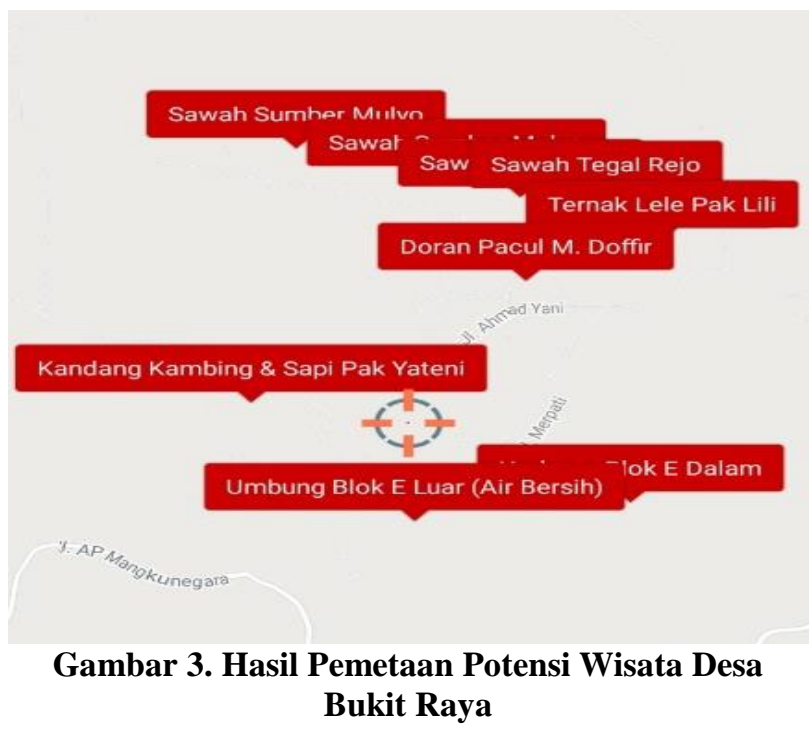

Metode berbasis sampel digunakan sebagai alat penyelesaian dan mengidentifikasi kemungkinan karakteristik yang digunakan langsung dari pengalaman desain sebelumnya, seperti standar ruangan dan fitur gaya desain yang dapat diprogram.

Setelah melakukan survey lapangan peneliti telah membuat desain awal (site plan) untuk Kawasan Agrowisata Bukit Raya seperti pada gambar 4, namun masih dapat dikembangkan menjadi desain 3D yang akan dibahas pada penelitian selanjutnya.

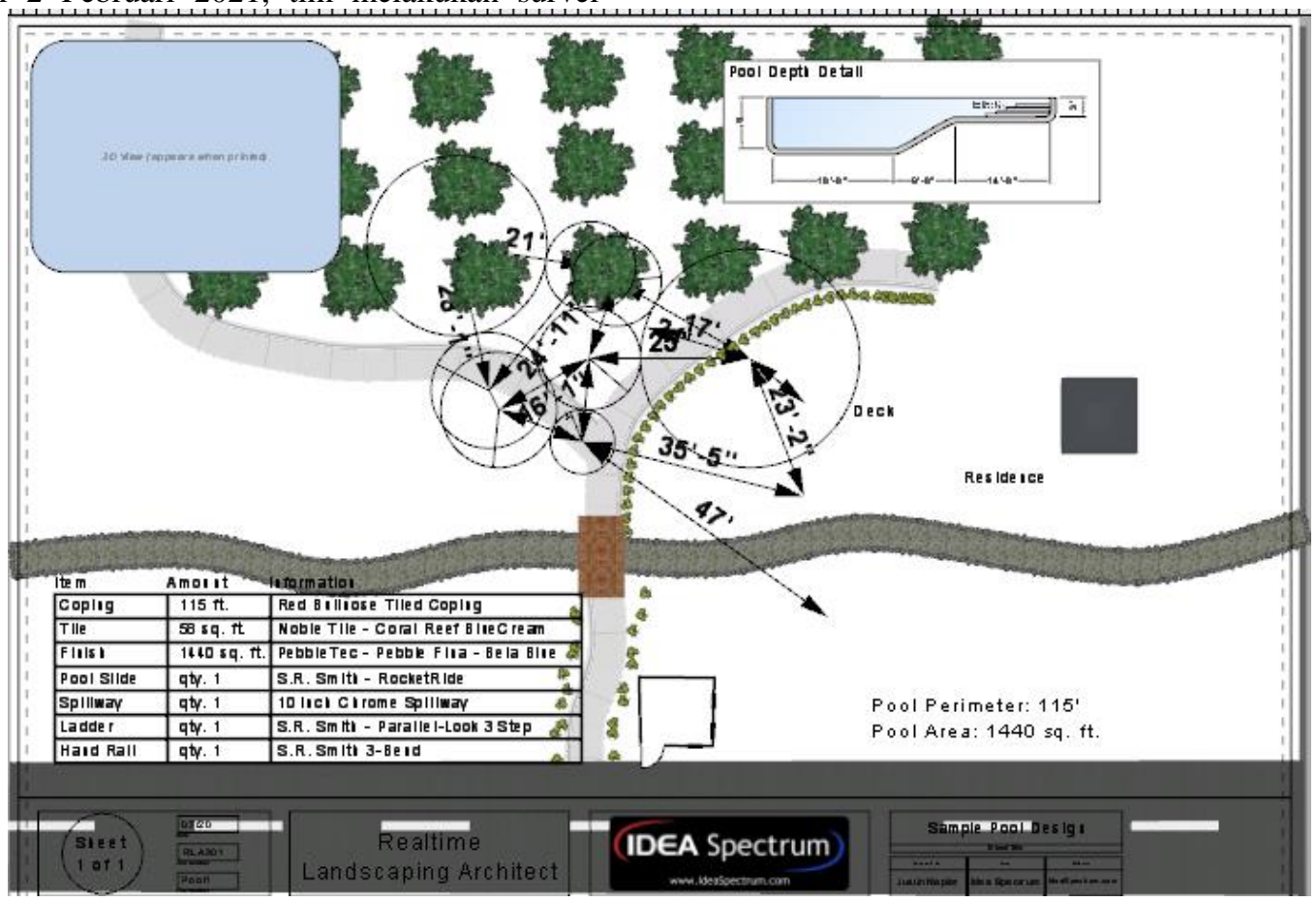

Gambar 4. Rancangan Desain Kawasan Agrowisata Desa Bukit Raya 


\subsection{Desain Ideal Agrowisata}

Jenis penggunaan lahan ini dirancang untuk memfasilitasi penggunaan properti secara berkelanjutan untuk tujuan pertanian dan di area terbuka. Jika pembangunan non-pertanian diinginkan, maka dampaknya terhadap daerah yang masih alami dan kegiatan pertanian di sekitarnya harus diminimalkan (Mandiangan, 2013). Desain ini dirasa cocok untuk semua pengembangan agrowisata khususnya di daerah pedesaan, dengan catatan sebagai berikut:

1. Meminimalkan penebangan, penimbunan kembali dan perataan jalan.

2. Tumbuh langsung pada fitur geologi seperti singkapan berbatu atau lereng.

3. Manfaatkan kegagalan yang signifikan dan penggunaan serta struktur non-pertanian yang terkonsentrasi.

4. Diperlukan lahan yang luas dengan minimal hektare, dengan persentase kecil dari lokasi yang kemungkinan akan disisihkan untuk tujuan nonpertanian.

5. Penggunaan non-pertanian harus ditempatkan berjauhan sehingga konsentrasinya tidak mempengaruhi karakter pertanian daerah tersebut.

6. Desain arsitektur dan perencanaan lokasi berkualitas tinggi menggunakan tema desain yang menggabungkan struktur yang konsisten dengan karakteristik ruang pedesaan terbuka di daerah tersebut.

\subsection{Kategori Agrowisata}

Penggunaan yang sesuai dengan tujuan utama pertanian dan penggunaan pertanian lainnya termasuk pemeliharaan ternak, berkuda, lumbung dan perumahan. Gabungan penggunaan kembali area perumahan dan pengembangan pedesaan serta pertanian di area yang luas. Lokasi dan karakteristik yang diinginkan pengembangan bisnis, pariwisata dan pertanian harus meminimalkan dampaknya terhadap kawasan alam, ruang terbuka dan kegiatan pertanian di Bukit Raya. Penggunaan tidak boleh dikonsentrasikan secara paralel, tetapi harus dikonsentrasikan di satu wilayah kabupaten untuk menciptakan hubungan simbiosis antara penggunaan ini dan dengan konsentrasi yang cukup untuk terus menciptakan dan mempromosikan kegiatan (Tokan, 2014).

\subsection{Potensi Hambatan}

Meskipun sangat mungkin bahwa pengembangan agrowisata dapat berhasil integrasi ke dalam komunitas lokal di Desa Bukit Raya tanpa adanya gangguan besar, namun ada beberapa tantangan yang potensial. Perencanaan agrowisata memerlukan perhatian terhadap potensi dampak terhadap lingkungan dan persaingan kepentingan masyarakat petani. Masyarakat seringkali khawatir terhadap kemungkinan kebisingan, lalu lintas dan pelanggaran lainnya, karena dampak tersebut dapat mengubah sifat umum masyarakat (Hossein, Alipour and Dalir, 2014).

Ada juga sejumlah alat yang dapat digunakan untuk mengurangi potensi hambatan. Tingkat kebisingan dapat mengurangi kualitas hidup pemilik tanah. Secara umum tingkat kebisingan di daerah pedesaan dan pertanian lebih rendah daripada di daerah perkotaan, lingkungan yang tenang ini merupakan ciri khas daerah pedesaan, namun kegiatan pertanian juga bisa sangat bising. Mobil, peralatan, truk, dan hewan mengeluarkan suara yang berbeda. Ketika mempertimbangkan apakah akan menyetujui pengembangan agrowisata, perencana lokal harus menentukan apakah kebisingan dari agrowisata serupa atau berbeda dari kebisingan yang biasa ditemukan di daerah pedesaan dan pertanian Bukit Raya. Jika kebisingan berbeda seperti daerah sekitarnya, perencana lokal harus mempertimbangkan apakah kegiatan tersebut akan dilakukan setiap hari atau hanya musiman. Bagi perusahaan lain, peningkatan lalu lintas juga bisa menjadi masalah bagi pemilik tanah.

Pemerintah daerah dapat menggunakan rencana pengelolaan lalu lintas untuk menentukan perkiraan volume kendaraan dan penggunaan jalan umum yang diharapkan untuk mengidentifikasi potensi dampak lalu lintas. Untuk meminimalkan bahaya lalu lintas jalan tambahan, kegiatan agrowisata di Desa Bukit Raya harus menyediakan parkir di luar badan jalan yang memadai. Penyeberangan pejalan kaki menjadi perhatian bagi penyedia layanan agrowisata dan pemilik tanah di sekitarnya. Operator harus secara teratur memeriksa area di mana akses dilarang.

Selain itu, para petani di Bukit Raya memiliki beberapa kepentingan dalam pendapatan mereka yang mungkin saling bertentangan. Kekhawatiran para petani yang juga bekerja sebagai pemilik tanah, pemilik bisnis, pembayar pajak, dan anggota masyarakat dapat berbedabeda menurut subjeknya. Misalnya, seorang petani yang secara aktif mengalihkan kegiatannya kepada generasi muda dapat mendukung kebijakan yang membatasi pengembangan di luar pertanian. Di sisi lain, petani yang berencana untuk meninggalkan industri dalam waktu dekat cenderung menekankan kepentingan mereka sebagai pemilik tanah untuk memaksimalkan nilai properti mereka. Berbagai jenis peternakan juga dapat memiliki prioritas yang berbeda. Masyarakat harus memperhitungkan keragaman lokal dalam pertanian untuk memastikan bahwa semua manfaat diperhitungkan secara matang dengan kelompok sadar wisata dan masyarakat yang memiliki lahan pertanian.

\section{KESIMPULAN}

Desa Bukit Raya berpotensi untuk dikembangkan menjadi kawasan agrowisata di Kutai Kartanegara. Produk unggulan yang ditawarkan adalah industri pertanian masyarakat dan kehidupan masyarakat sebagai kearifan lokal yang menarik. Langkah awal yang dapat dilakukan oleh masyarakat dan aktor desa adalah merancang kawasan stasiun yang lengkap dan diterima 
oleh seluruh masyarakat. Artikel ini menjadi pedoman bagi pengembangan desa wisata Bukit Raya. Perancangan kawasan pertanian dilakukan dengan menggunakan pendekatan perencanaan, zonasi dan desain arsitektur menggunakan penanda peta dan perangkat lunak lansekap. Hasil perencanaan desa Bukit Raya dibandingkan dengan konsep kategori agrowisata dan dianalisis sesuai dengan potensi kendala yang mungkin dihadapi masyarakat.

\section{SARAN}

Saran untuk penelitian lanjutan dengan topik riset dan pengembangan lebih menekankan pada perumusan kebijakan partisipatif dalam implementasi rancanganrancangan yang sudah disepakati bersama dengan tambahan metode dan pendekatan dalam perumusan kebijakan. Seperti analisis terhadap dampak lingkungan secara mendalam jika dilakukan pembangunan kawasan agrowisata yang sedikit atau banyaknya telah berubah bentuk dan pola kawasan pertanian secara alami. Sehingga hasil kajian yang diperoleh tidak hanya konsentrasi terhadap peluang-peluang pendapatan masyarakat tetapi juga peluang-peluang terhadap pelestarian lingkungan serta kawasan pertanian yang subur. Masyarakat Desa Bukit Raya juga memberikan feedback yang positif terhadap hasil penelitian ini, karena masterplan pembangunan Bukit Raya menjadi Desa Wisata akan diusulkan ke Kementerian Desa pusat oleh Kepala Desa Bukit Raya.

\section{DAFTAR PUSTAKA}

Andin, N. 2013. Agrowisata Di Desa Wisata Studi Kasus: Desa Wisata Kembangarum , Ka ...', Jurnal Perencanaan Wilayah dan Kota, 24(3), pp. 173-188. Available

at: https://d1 wqtxts1 xzle7.cloudfront.net/44121571/J urnal-2-Nurulitha-with-cover-page-

v2.pdf?Expires $=1632370287 \&$ Signature $=\mathrm{FaS} \sim \mathrm{E}$ DqSRNf1sI0nAJyb3DCMEIq616AQ3Xvs1SfzW ZCnQ4VPmGF HrtalkiTtg ZoODxMREDbjne p1nTWE8Ju2IWqgE8ulFQ5oaanBJ8E q7ypiAV o6ol8L00N6mn7S1gRp-UHWh.

Badan Pusat Statistik Kabupaten Kutai Kartanegara. 2020. Kecamatan Tenggarong Seberang dalam Angka 2020. Kutai Kartanegara: CV. Mahendra Mulya.

Bihamding, H. 2017. Perencanaan Pembangunan Partisipatif Desa. Sleman: Deepublish.

Damanik, J. dkk. 2015. Membangun Pariwisata dari Bawah: Catatan Penelitian terhadap Desa Wisata Penerima PNPM Mandiri Pariwisata. Yogyakarta: Gadjah Mada University Press.

Goodwin, H. and Santilli, R. 2017. 'Community Based Tourism: a Success?', in. None: ICRT Occassioal Paper 1, pp. 1-7.

Hermantoro, H. 2017. Memahami Konsep Dasar Pariwisata. Depok: Aditri.

Hossein, G. O., Alipour, H. and Dalir, S. 2014. 'An
Entrepreneurial Tourism Project through AgroTourism Farm in Iran', Journal of Sustainable Development Studies, 6(1), pp. 48-63.

Indrawati, V. 2019. 'Kawasan Agrowisata Organik di Pontianak', Jurnal Online Mahasiswa S1 Arsitektur UNTAN, 7, pp. 1-15. Available at: https://jurnal.untan.ac.id/index.php/jmarsitek/artic le/view/31501.

Jafaruddin, N., Noor, T. I. and Karyani, T. 2020. 'Variables Influencing the Potency of Community Based Coffee Agro-Tourism in Mount Galunggung, Tasikmalaya, Indonesia', Pelita Perkebunan (a Coffee and ..., 36(3), pp. 264-276. doi: 10.22302/iccri.jur.pelitaperkebunan.v36i3.454.

Kementerian Hukum dan Hak Asasi Manusia. 2009. Undang-undang Republik Indonesia Nomor 10 Tahun 2009 tentang Kepariwisataan. Indonesia: Sekretariat Negara: Kepala Biro Peraturan Perundang-undangan.

Lee, S.-W. and Nam, S.-Y. 2007. 'Agro-Tourism as a Rural Development Strategy in Korea', Journal of Rural Development, 30(1), pp. 67-83.

Mandiangan, M. M. 2013. 'Kawasan Agrowisata Di Rurukan - Arsitektur Organik', Jurnal Arsitektur DASENG, 2(1), pp. 9-18.

Marinovski, C. 2018. Community Development Approach to Community Based Tourism: The Case of Beni Na'im in Palestine. Helsinki: University of Helsinki.

Paneva, K. K. 2018. Tourism Development in The Province of East Java Through Agrotourism. Surabaya: Department of Architecture, Intitute of Technology Sepuluh November.

Putra, G. B., Arkan, F. and Atmaja, E. J. J. 2020. 'Building Banyuasin Village, Bangka Regency as green and agro-tourism village that sustainable using information technology', IOP Conference Series: Earth and Environmental Science, 599(1). doi: 10.1088/1755-1315/599/1/012081.

Srithong, S., Suthitakon, N. and Karnjanakit, S. 2019. 'Participatory Community-based Agrotourism: A Case Study of Bangplakod Community, Nakhonnayok Province, Thailand', SSRN Electronic Journal, 8(1), pp. 212-220. doi: 10.2139/ssrn.3398859.

Sukmana, E., Brahmantyo, H. and Hira, T. 2020. 'Analisis Potensi Wisata Berbasis Budaya dengan Pendekatan Community Based Tourism (CBT) di Desa Budaya Lung Anai, Kutai Kartanegara', EDUTOURISM Journal Of Tourism Research, 1(2), pp. 1-11. doi: 10.53050/ejtr.v1i2.122.

Sukmana, E., Brahmantyo, H. and Mumin, A. T. 2018. 'The Influence of Community Participation, The Role of Village Government, Number of Tourist Visits, and Village Income on Community Welfare in Cibuntu and Citundun Tourism Villages', TRJ Tourism Research Journal, 2(2), p. 
61. doi: 10.30647/trj.v2i2.37.

Tokan, M. R. L. 2014. 'Kawasan Villa Dengan Penataan Landsekap Agrowisata di Kota Singkawang', Kawasan Villa Dengan Penataan Landsekap Agrowisata, 2, pp. 91-102. Available at: http://jurnal.untan.ac.id/index.php/jmarsitek/articl e/view/6383/6579.

UNWTO - United Nations World Tourism Organization. 2015. Making Tourism More Sustainable: A Guide for Policy Makers. Madrid: UNWTO.
Wulandari. 2017. Jatung Utang sebagai Pengiring Tari Hudog pada Masyarakat Suku Dayak Kenyah di Desa Sungai Payang Kec. Loa Kulu Kab. Kutai Kartanegara. Yogyakarta: Institut Seni Indonesia.

\section{UCAPAN TERIMA KASIH}

Tim Peneliti mengucapkan yang sebesar-besarnya atas pendanaan hibah penelitian dasar yang diberikan oleh Politeknik Negeri Samarinda melalui Pusat Penelitian dan Pengabdian Masyarakat (P3M). 